\title{
The Descriptions of Date Palms and an Ethnomedicinal Importance of Dates Mentioned in the Quran
}

\author{
Mohd Khairul Nizam Zainan Nazri \\ Adnan Mohamed Yusoff \\ Nur Farhah Zainan Nazri \\ Najm Abdul Rahman Khalaf
}

Asma Abdul Rahman

Faculty of Quranic and Sunnah Studies, Islamic Science University of Malaysia, Malaysia Corresponding Author Email: drknizamzn@usim.edu.my

\section{Doi:10.5901/mjss.2016.v7n2p405}

\section{Abstract}

\begin{abstract}
The present work is a part of list of the total twenty seven references to date palm contained in the 114 chapters of the Qur'an and their interpretations also a special focus on an ethnomedicinal importance of dates highlighted by the Qur'an which is to facilitate the childbirth. The main objective of this study is to establish how the different parts of date palm had been described by Allah and understood by the interpreters as well as the benefit of dates; to ease the labor pain. In view of the significance of this study, comprehensive and detailed data was systematically collected from the Qur'an, significant books of commentary, references written on the Islamic medicine and scientific findings. The study found that the parts of date palm which have been described by the Qur'an are: its spadix, trunk, nucleus and tree. The date palm spadix is described as soft, producing clusters of dates hanging low and near and being arranged and layered one above another. The trunk is said to be very uneven and rough; most suitable for crucifixion and to be attached to during childbirth. The dead trunks are illustrated by the features of hollow and uprooted. The date palms are featured by grown from water; resembling other types of plants, some of them come from a single stem root and some are not, produce sheathed fruit-stalks; enclosing dates and yield fruits of different taste which regarded as superior food and fruits. They are also described as good and produce fruits annually. Strong drink i.e. liquor could be also derived from dates i.e. before its prohibition. The nucleus of dates are characterized by the three small parts hidden known as al-fatil; something which is in the long slit of a date-stone, al-naqir; speck on the back of a date-stone and al-qitmir; the thin membrane over the date-stone. The use of dates before delivery; reduces the need for induction and augmentation of labour and after delivery; decreases bleeding.
\end{abstract}

Keywords: Tafsir, Date Palm, Date Palm Spadix, Date Palm Trunk, Nucleus of Dates, Childbirth

\section{Introduction}

Plants are essential component of the universe. Human beings have used plants as medicine; preventive or curative from the very beginning of time. After various observations and experimentations medicinal plants were identified as a source of important medicine, therefore, treatment through these medicinal plants began in the early stages of human civilization. Approximately, $70 \%$ of the homeopathic drugs are prepared from the fresh plants. (Marwat, 2009, p. 284)

In fact, there has never been a greater demand for natural remedies as increasingly people search for treatments that are effective yet safe. Fears about the harmful side-effects of some prescription drugs, for instance, are prompting people to seek alternatives whenever possible. Moreover, today's high-tech medicine with its surgical procedures that treat a specific part of the individual has led many people to resent the impersonal nature of their health care and yearn for treatment that takes account of the whole person. (Bean, 1996, p. 8-9)

Dates (Phoenix dactylifera) regarded as preventive or curative, have been recorded as part of human diet since antiquity and throughout major human civilizations including the biblical traditions. Dates are robust, flexible and long lasting plant that can survive in a harsh environment. In Arabic, it is known as al-nakhl, which etymologically means "good, nourishing and nice smelling".

Historically, in the days of the Prophet (the $6^{\text {th }}$ and $7^{\text {th }}$ century A.D.), the oases of Arabia's immense deserts 
counted but small numbers of permanent inhabitants. They cultivated the date palm described as 'the aunt and mother of all Arabs, the tree of trees, of which not only the fruits but all the parts are used, yielding the only solid food - sometimes completed by camel milk - for the bulk of the miserable Bedouins'. The Quraysh considered date palm as divine and sacred. Thus, besides believing that their goddess al-lata was one of the daughters of Allah, they made the date palm one of her symbols and as such it was paid divine honors. Another deity was al-Uzza, said to reside in a palm grove at Nakhla in Northern Arabia. Among the famous sayings to testify the precious tree such as: "And the earth He has prepared it for the living tribes. Therein are fruits and the palm with sheathed clusters" and also a verse related to the pains of childbirth came upon Maryam near the trunk of a palm. (Warda, 1995, p. 76-81)

\section{Materials and Methods}

This study is focusing on the 27 verses related to date palms and their interpretations and a benefit of dates highlighted in the Qur'an; easing the childbirth. This article is based on literature reviews and writer's analysis. The researcher will take several steps in the study; firstly, collecting verses related to date palms, secondly, analysing the collected interpretations of the verses according to Allah's purpose, thirdly, discussing the advantage of dates to ease the child birth based on Islamic and scientific findings.

\section{Quranic Descriptions of the Date Palm}

\subsection{Quranic Descriptions of the Date Palm Spadix (Al-Tal')}

The significance and versatility of the date palm are borne out by the fact that this fruit and its blessed palm find mentioned in the Qur'an for 27 times as nakhl, ${ }^{1}$ nakhla, ${ }^{2}$ al-nakhlah, ${ }^{3}$ nakhil ${ }^{4}$ and others ${ }^{5}$.

Allah has mentioned and described a significant part of the date palm which is the spadix (al-tal') in three different places. He mentions one of the characteristics of the date palm as having soft spadix. He says in Surah al-Shu'ara', verse 148:

\section{"And green crops (fields etc.) and date-palms with soft spadix."}

The main focus was given to the meaning of the word al-hadim. Ikrimah and Qatadah for instance assert that alhadim represents soft and fresh date. Al-Dahhak adjoins that it happens if it abundantly produces fruits and then putting them together; also symbolizes al-hadim. Al-Murrah says that it refers to spadix when grown and become green. AlHassan al-Basri says that it has no seed -seedless-. Abu Sakhar reveals that al-hadim begins when the spadix attached to one another. (Ibn Kathir, 1999, p. 155) The interpretations made by the scholars regarding the verse are observed to be interrelated.

Figure 1: The soft spadix of date-palms.

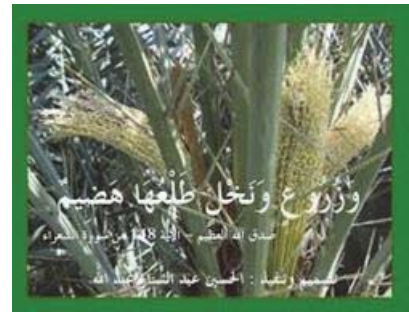

\footnotetext{
${ }^{1}$ Surah al-An'am: 99, 141; al-Kahf: 32; Taha: 71; al-Shu'ara': 148; Qaf: 10; al-Qamar: 20; al-Rahman: 11, 68 and al-Haqqah: 7. See: 'Abdul Baqi, Muhammad Fuad, al-Mu'jam al-Mufahras li Alfaz al-Qur'an al-Karim (Beirut: Dar al-Fikr \& Dar al-Ma'rifah, 1994$), 863$.

${ }^{2}$ Surah 'Abasa: 29. See: 'Abdul Baqi, al-Mu'jam al-Mufahras li Alfaz al-Qur'an al-Karim, 863.

${ }^{3}$ Surah Maryam: 23, 25. See: 'Abdul Baqi, al-Mu'jam al-Mufahras li Alfaz al-Qur'an al-Karim, 863.

${ }^{4}$ Surah al-Baqarah: 266; al-Ra'd: 4; al-Nahl: 11, 67; al-Isra': 91; al-Mu'minun: 19 and Yasin: 34. See: 'Abdul Baqi, al-Mu'jam al-Mufahras li Alfaz al-Qur'an al-Karim, 863.

${ }^{5}$ Surah al-Nisa': 49, al-Isra':71, 53; Ibrahim: 24, 25; al-Hashr: 5 and Fatir: 13. See: Al- Sijistani, Abu Hatim, Kitab al-Nakhl, edited by Ibrahim al-Sammaraa, (al-Mamlakah al-'Arabiyyah al-Su'udiyyah: Dar al-Liwa' \& Beirut: Muassasah al-Risalah, 1985), 33, 37, 48, 64, 71. 
Then, the Quran discloses another characteristic of the date palm spadix which brings clusters of dates hanging low and near, Allah says in Surah al-An'am, verse 99:

\section{"...And out of the date-palm and its spathe come forth clusters of dates hanging low and near..."}

It contains three important terms concerning the date palm; al-tal', al-qinwu and al-daniah. Al-tal' (the spadix) refers to the container of the branch of date palm which seems to be the first appearance as a great citron - shrubby tree bearing large lemon-like fruits with thick fragrant peel closed on the branch, then opens up like a picture of boots, next a bunch come out together, it is called al-ighrid (the spadix) and then it becomes al-qinwu (bunch of dates).

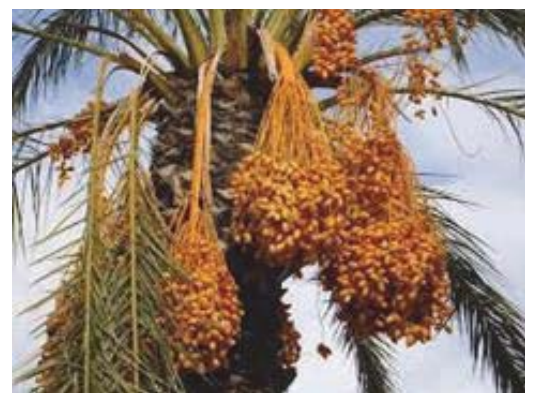

Figure 2: Al-tal' (the spadix) of date palm brings forth al-qinwu (clusters of dates) al-daniah (hanging low and near).

Al-daniah connotes closeness. It signifies the low and near distance to pluck. Al-qinwan al-daniah (clusters of dates hanging low and near) is a part of al-qinwan al-nakhl (clusters of date palm) singled out here as integrating to favor during the recall of the completion and perfection of the creation. (Ibn 'Ashur, 2000, p. 53)

The last characteristic of the date palm spadix which has been described by Allah is that it is being arranged and layered one above another, in Surah Qaf, verse 10:

"And tall date-palms; with ranged clusters."

The main discussion is regarding wa al-nakhl basiqat and laha tal' nadid. Ibnu Jarir says that wa al-nakhl basiqat signifies the height. In addition, Ibnu Jarir and Ibnu al-Mundhir it denotes the straightness. Ibnu al-Mundhir says that its height is coiling or winding or twisting into a continuous circular or spiral shape; curling round and round. Ibnu Jarir and Ibnu Abi Hatim view that laha tal' nadid indicates the growth or increase by mean of gradual additions by each other. (AlSayuti, 2003, p. 276)

In addition, Ibnu Kathir says that it also shows that -the tree- is very tall and high. Ibnu Abbas and others opine that al-basiqat is similar to al-tiwal which means very tall or high as a palm tree. Laha tal' nadid means mandud; being arranged and layered one above the other. (Ibn Kathir, 1999, p. 396) In short, wa al-nakhl basiqat signifies a feature of date palm that is being very tall and high while laha tal' nadid connotes a feature of its spadix as being arranged and layered one above the other.

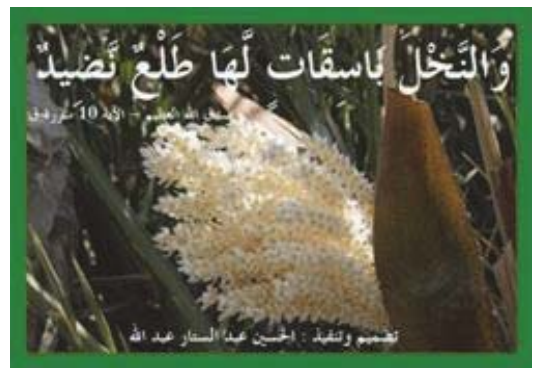

Figure 3: The tall date-palms; with ranged clusters. 


\subsection{Quranic Descriptions of the Date Palm Trunk (Al-Judhu'And Al-A'jaz)}

The date palm trunk has been categorized as is the roughest trunk of the tree thus, the most appropriate for crucifixion and to be attached to during labor pains. verse 71:

Allah has recorded the saying of Fir'aun during the crucifixion of Musa on the trunks of date-palms in Surah Taha,

Fir'aun (Pharaoh) said: "...I will surely crucify you on the trunks of date-palms..."

Shanqiti is of the opinion that Pharaoh decided to crucify the believers on the trunks of date-palms as the trunk is the roughest trunk of the tree trunks. Hence, the crucifixion on the trunks of date-palms is worse than the crucifixion on the trunks of other kinds of tree as renowned. (Shanqiti, 1988, p. 134)

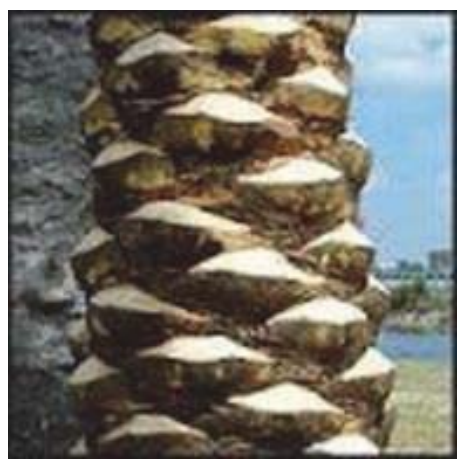

Figure 4: The rough though trunk of date palm tree.

Allah also emphasizes that the tough trunk of date palm tree is most suitable to be attached to during childbirth. In Surah Maryam, verse 23:

"And the pains of childbirth drove her to the trunk of a date-palm..."

Abi Ubaidullah says that the verse signifies the dried date-palm which she -Maryam- used to shake and used as a shelter which is called Bethlehem. Abi Qudamah argues that a date-palm had been planted for Maryam for her to attach to as a woman needs to attach to another woman at birth. (Al-Sayuti, 2003, p. 454)

Ibnu Kathir says that it specifically refers to the place where the date-palm turned down to serve Maryam. (Ibn Kathir, 1999, p. 223)

Shanqiti reveals that some scholars say that the date palm trunk which Allah ordered Maryam to shake was troubled dried; yet when it was shaken by her, Allah made it; a palm with ripe fresh dates. Other scholars are of the view that the palm trunk sprung but it was not fruitful, when it was shaken Allah sprouted fruits; fresh ripe dates. Some scholars believe that the date palm was fruitful and Allah ordered Maryam to shake it; to get the ripe fresh dates. He adds whoever understands the context of the Qur'an will realize that Allah granted Maryam the ripe fresh dates -either the date palm tree has been seen as dried or non-productive- as well as flew the river for her as extraordinary as they were not exist before.

Al-makhad or labor pain means al-talq which refers to a wrench birth and it is derived from al-makhd; a strong movement to the severity of the fetus' movement in the mother's womb whenever he/she struggle to get out. (Shanqiti, 1988, p. 452-458)

The word date-palm trunk is either connotes the common dominant name which is recognized by people in the desert as per the definition of star or the specific type of date-palm trunk in which Allah guided her to rely on, to get fresh ripe dates to ease the labor pains. It is due to the fact that the date palm is less tolerant to coldness and its fruits; dates appear from the palm pith, fitting the ayah which mentioned the particular trunk of a date-palm chosen during the pains of childbirth to be relied on.

Al-Razi mentions three possible factors which drove Maryam to the trunk of a date-palm; firstly, to ease the labor pains, secondly, to strengthen and rely on it and finally, to protect her from the people; accusing a chaste woman of 
adultery, thus she wished to die.

He the Almighty adds in Surah Maryam, verse 25:

\section{"And shake the trunk of date-palm towards you; it will let fall fresh ripe-dates upon you."}

A date-palm which could be attached to at birth was grown for Maryam.

The trunk of a date-palm which Maryam which the pains of childbirth drove her to has no pollen, thus Allah grows the pollen for it also fresh ripe-dates; when it was shaken all fruits were fallen. (Razi, 1992, p. 291)

Al-Tabari in his commentary on the verse cites a narration from 'Amru Bin Maimun; he says that both; dried and fresh dates are the best thing in postpartum period. (Al-Tabari, 2000, p. 179)

Allah uses the date palm trunk as parable. At the same time He mentions two features of the date palm trunks; khawiyah and mun'aqir. He says in Surah al-Haqqah, verse 7:

"...so that you could see men lying overthrown (destroyed), as if they were hollow trunks of date-palms!"

Qatadah accentuates that the verse refers to trunks of date-palms whereby its roots remain but its lofty part ends. Ibnu 'Abbas says that a'jaz means trunks of date-palms and khawiyah means ruins and others say that it connotes obsolete which happens when the wind hit -one of the infidels- the head on the ground thus, he fall down and died and his brain was broken into small pieces. Therefore the body remained dead as an established date palm that fells down without branches. (Al-Sayuti, 2003, p. 209)

Ibnu Kathir reveals that it indicates the bodies -of the infidels- remained headless as the wind came and uprooted the head and move it up through the air. Then, it degenerate the head and breaks the brain into small pieces as uprooted date palm. (Ibn Kathir, 1999, p. 209)

It is possible to say: nakhl mun'aqir, mun'aqirah and mun'aqirat (uprooted date-palms), nakhl khawin, khawiyah and khawiyat (hollow date-palms) and nakhl basiq, basiqah and basiqat (high date-palms). (Razi, 1992, p. 498)

Furthermore, in Surah al-Qamar, verse 20:

"Plucking out men as if they were uprooted stem of date-palms."

Mujahid says that it reflects the infidels' heads resemble trees and their necks resemble uprooted stem of datepalms. (Al-Sayuti, 2003, p. 344)

It infers the strength and intensity of the wind. Al-naz' means the removal of something aggressively until all disappeared and separated from what was connected to it. Al-nas refers to those who were destroyed of the Prophet Hud's people. Al-a'jaz is the plural of 'ajz which is the nape and below of something. A'jaz al-nakhl refers to its trunks which establish it. It exemplifies the whole date palms apart from the branches. (Tantawi, 2007, p. 4027)

Mun'aqir is fa'il of inqa'ara which means its bottom loses or is easily to be cut i.e. reaching the bottom by drilling or digging. It has been said: so and so is digging the well i.e. whenever ending at lowest depth as the internal side of date palms trunks loses. The wood of date palms appears if the interval/stand raised grew long. Mun'aqir is wasf (description) of nakhl (date palm) which is used as mufrad (singular) and mudhakkar (male) even though nakhl is used regardless of number; i.e. neither mufrad (singular) nor jama' (plural) contrary to the ayah: Kaanahum a'jaz nakhl khawiyah and wa alnakhl dhat al-akmam. (Al-Sayuti, 2003, p. 240)

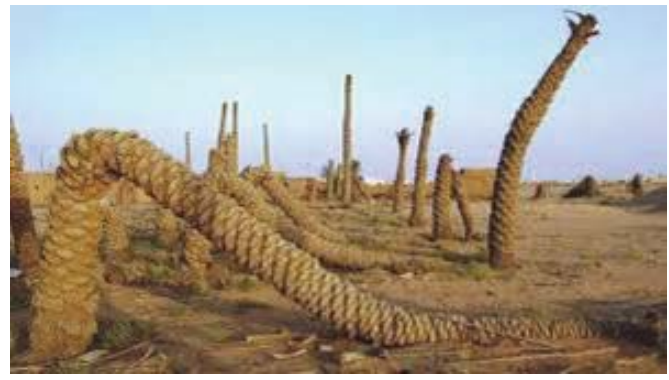

Figure 5: The hollow and uprooted stem of date-palms. 


\subsection{Quranic Descriptions of the Date Palm (Al-Nakhl and Al-Nakhil)}

Allah affirms that the date palm and grapes share the same feature; grown from the same source i.e. water. In Surah alNahl, verse 11:

"With it He causes to grow for you the crops, the olives, the date-palms, the grapes, and every kind of fruit..."

It indicates that the earth brings forth all crops from the same source; i.e. water.

Shanqiti says that it verifies the existence of the Day of Resurrection. (Shanqiti, 1988, p. 469)

It completely explains the benefits of water. (Tantawi, 2007, p. 2504)

It implies the argument against the infidels. (Al-Tabari, 2000, p. 179)

After that, Allah proclaims another feature of the date palms that some of them come from a single stem root and some are not; as He says in Surah al-Ra'd, verse 4:

"And in the earth are neighboring tracts, and gardens of vines, and green crops (fields etc.), and date-palms, growing out two or three from a single stem root, or otherwise (one stem root for every palm), watered with the same water, yet some of them We make more excellent than others to eat..."

The word al-sinwu is regarded as the main focus of interpreters. Some of them view that it means similar or equivalent as the saying: the man's uncle is synonymous with his father i.e. like him. Generally, one stem root for every twig which resembles others out of one root. Sinwan refers to date palm combined with other date palm out of one root while ghair sinwan refers to date palm which does not combine with other date palm out of one root. (Tantawi, 2007, $\mathrm{p}$. 2359)

Tha'lab reported from Ibnu al-A'rabi that al-sinwu means equivalent or parallel as per saying: "Indeed the uncle of the man is synonymous with his father", i.e. like him. Therefore, the first interpretation of the word al-sinwu is palm trees are either have the same root or not and the second interpretation is palm trees are either identically similar or not. (Razi, 1992, p. 142) verse 11:

Also, Allah conveys that the date palm produces sheathed fruit-stalks which enclosing dates in Surah al-Rahman,

"Therein are fruits, date-palms producing sheathed fruit-stalks (enclosing dates)."

The verse is mentioned separately for its distinction and usefulness; wet and dry. Ibnu Juraij says that it connotes the pollen-vessels. This is the opinion of the majority of the commentators; in which bunch of dates rise from them, then split from clusters, next become busr and after that rutab afterward ripen, accomplish and rise as red, reddish-brown or white. (Ibn Kathir, 1999, p. 490)

Figure 6: The sheathed fruit-stalks of date-palms.

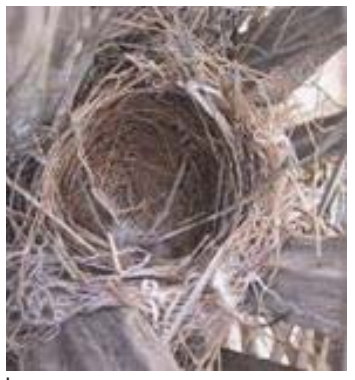

Besides, Allah expresses that the date palm produces fruits of different taste in Surah al-An'am verse 141:

"And it is He Who produces gardens trellised and non-trellised, and date-palms and crops of different shape and taste (its fruits and its seeds) and olives, and pomegranates, similar (in kind) and different (in taste)..."

It indicates that Allah has produced palm trees and crops of different taste which means "by eating", the fruit. Allah 
has created date palm and crop of different shape and taste (its fruits and its seeds) and olives and pomegranates similar (in kind) and different (in taste) of sweet, sour and bitter. (Al-Tabari, 2000, p. 157)

The Quran has persistently highlights the significance of the date palm as well as its fruits; as superior food and fruits; in Surah al-Mu'minun verse 19:

"Then We brought forth for you therewith gardens of date-palms and pomegranates, wherein is much fruit for you, and whereof you eat."

It is a clear proof for the infidels that Allah is able to do in accordance with His wills. It includes the resurrection of the dead from His creation and returns it after demise; as per the form before the demise. Moreover, Allah is able to revive the death land which is neither having plants nor crops. Therefore, Allah brings down rain from the sky producing plants as staple food. (Al-Tabari, 2000, p. 514)

Allah has specifically mentioned date-palms and grapes due to their numerous benefits; as food and fruits in Surah al-Rahman verse 68:

"In them (both) will be fruits, and date- palms and pomegranates."

Ibnu Kathir mentions that the verse: "... and date-palms and pomegranates," is related to 'ataf al-khas (specific) on al-'am (general) as determined by al-Bukhari and others but rather the words; date- palms and pomegranates have been mentioned independently for their superiority over others. (Ibn Kathir, 1999, p. 507)

In Surah al-'Abasa verse 29:

"And olives and date-palms."

It refers to the two well-known trees; i.e. olives and date-palms for their outstanding benefits and useful fruits. (Tantawi, 2007, p. 4444)

In Surah Yasin verse 34:

"And We have made therein gardens of date-palms and grapes and We have caused springs of water to gush forth therein."

Date-palms and grapes were honored by the people of Hijaz as they might be the finest fruits in the world. (Ibn Kathir, 1999, p. 575) Allah has specifically mentioned palms and grapes as they are known to have blond color and advantageous fruits. (Tantawi, 2007, p. 3535)

The Quran also admits that strong drink i.e. liquor could be derived from dates i.e. before its prohibition in Surah alNahl verse 67:

"And from the fruits of date-palms and grapes, you derive strong drink (this was before the order of the prohibition of the alcoholic drinks) and a goodly provision..."

Ibnu 'Abbas says that al-sakar refers to any unlawful thing which is made from grapes or dates. In contrast, al-rizq al-hasan connotes any lawful thing which is made from them. In another narration, al-sakar reflects the prohibition and alrizq al-hasan signifies the permission including dried dates and raisins also al-tila'; a drink cooked from grape juice, aldibs; a syrup/sweet liquid obtained from date and its juice, vinegar and wine which are regarded as lawful drinks before they become strong as mentioned in various hadith. (Ibn Kathir, 1999, p. 581)

Allah uses the date palm (al-nakhl and al-nakhil) as parables too. He says in Surah al-Kahf verse 32:

"And put forward to them the example of two men; unto one of them We had given two gardens of grapes and We had surrounded both with date-palms; and had put between them green crops (cultivated fields etc.)."

Ibnu Kathir in his commentary mentions that after Allah talks about the infidels; proud to sit with the weak and needy Muslims and proud of their wealth and provision, then He made a parable of two men where Allah made "unto one of them We had given two gardens" that is two gardens of grapes, filled with date palms also crops that grow side by side. Each of the trees and crops in the blooming gardens is a very fruitful, palatable and abundance and thus He says: "Each of those two gardens brought forth its produce", which means producing fruit, He says: "and failed not in the least therein" that is did not detract from him anything, and then He further says: "and We caused a river to gush forth in the 
midst of them", that is the river comes from everywhere. (Ibn Kathir, 1999, p. 157)

In Surah al-Isra' verse 91:

"Or you have a garden of date-palms and grapes, and cause rivers to gush forth in their midst abundantly."

It implies the method of refutation also states that the infidels proposed three things: Firstly, to send down angels together with warnings or as witnesses of the truth who could assist the Prophet in preaching. Secondly, to grant treasures of wealth that could be spent. Thirdly, to grow gardens of fruits that could be enjoyed as food. (Shanqiti, 1988, p. 57)

Allah says in Surah al-Baqarah verse 266:

"Would any of you wish to have a garden with date palms and vines, with rivers flowing underneath and all kinds of fruits for him therein, while he is struck with old age and his children are weak (not able to look after themselves), then it is struck with a fiery whirlwind, so that it is burnt?"

It connotes the loss happened in old age as Allah says: "and the children are weak (not able to look after themselves as they are still young), then the garden is struck with a fiery whirlwind, so that it is burnt while the old man does not have either the ability or descendants to grow it again as per the infidels on the Resurrection Day; as they return to Allah they do not have any good thus, they will be blamed. Consequently, the old man does not be worthy of for any reward resembling the infidel who does not be worthy of the heaven.

(Ibn Kathir, 1999, p. 696)

\subsection{Quranic Descriptions of the Nucleus of Dates}

Allah has revealed and defined the date palm stone in three different places. Simultaneously, He sets forth parables with three small parts hidden in the nucleus of dates known as al-fatil, al-naqir and al-qitmir. In Surah al-Nisa' verse 49:

"...And they will not be dealt with injustice even equal to the extent of a fatila (a scalish thread in the long slit of a datestone)."

Al-naqir refers to the fovea in the nucleus which grows the date palm. Al-fatil refers to the incision nucleus and alqitmir refers to the skin which covers the nucleus. Al-fatil also refers to the slit in the belly i.e. interior of the nucleus. The ayah indicates that each righteous and malicious deed even as small as al-fatil (a scalish thread in the long slit of a datestone) will not be decreased. (Al-Sayuti, 2003, p. 141-142)

Ibnu Kathir says that Allah will not disregard any reward even as slight as a fatila (a scalish thread in the long slit of a date-stone). He reveals that ahl al-salaf (predecessor) opine that al-fatil connotes the incision nucleus. Ibnu 'Abbas accentuates that it refers to anything which comes out from between the fingers. Ibnu Kathir says that both opinions are interrelated. He also states that it also signifies something which is in the long slit of a date-stone. (Ibn Kathir, 1999, p. 333)

Ibnu 'Abbas, Ibnu Zaid and 'Atiyyah view that al-fatil means something which is in the interior of the nucleus. Mujahid, Qatadah and Al-Dahhak opine that it refers to something which is in the long slit of a date-stone. (Al-Tabari, 2000, p. 458)

Al-Razi opines that it refers to dirt that comes out from between the fingers is fa'il that connotes the meaning of maf'ul. (Razi, 1992, p. 230)

Allah further mentions in Surah al-Nisa' verse 53:

"Or have they a share in the dominion? Then in that case they would not give mankind even a naqira (speck on the back of a date-stone)."

Al-Tabari asserts that $A h l$ al-Ta'wil differed in the meaning of al-naqir. Ibnu 'Abbas says that it refers to something which is in the middle of the nucleus. 'Ata' Bin Abi Rabah, al-Dahhak and Abi Malik affirm that it also refers to something which is on the back of a date-stone. (Al-Tabari, 2000, p. 47)

Ibnu 'Abbas says that al-naqir refers to speck on the back of a date-stone. It also connotes the slit in the speck on the back of a date-stone which grows the date palm. (Al-Sayuti, 2003, p. 145)

Ahl al-Lughah (linguists) says that al-naqir refers to speck on the back of a date-stone which grows the date palm. 
It is a fa'il which is derived from al-naqr. It has been said that it refers to a hole cut in a piece of wood or stone to receive the tenon (the shaped end) of another piece and form a joint which is called al-minqar. Beak ores like an axe is able to cut the stones. It shows that they are so stingy; hoarding the wealth though they have very little. (Razi, 1992, p. 474)

In Surah Fatir verse 13:

"And those, whom you invoke or call upon instead of Him, own not even a qitmir (the thin membrane over the datestone)."

Ibnu 'Abbas says that al-qitmir refers to the skin and also implies the thin membrane over the date-stone and reported from Nafi' that it refers to the white fore skin over the date-stone. 'Ata' says that al-qitmir connotes the white membrane which is in between the date stone and date. It refers to the thin sheath of fibrous tissue that enclosing the date stone looks like onion skin which refers to the thin membrane over the date-stone or the speck on the back of a date-stone too. (Al-Sayuti, 2003, p. 408)

Al-Dahhak observes that it exemplifies the top of a date which connotes its cap. (Al-Sayuti, 2003, p. 269)

Al-qitmir refers to the thin membrane over the date-stone or the speck on the back of a date-stone resembling something that is less and worthless. This resembles those who worship other than Allah the Almighty who does not be similar to anything; even the smallest thing like the speck on the back of a date-stone. (Tantawi, 2007, p. 3506)

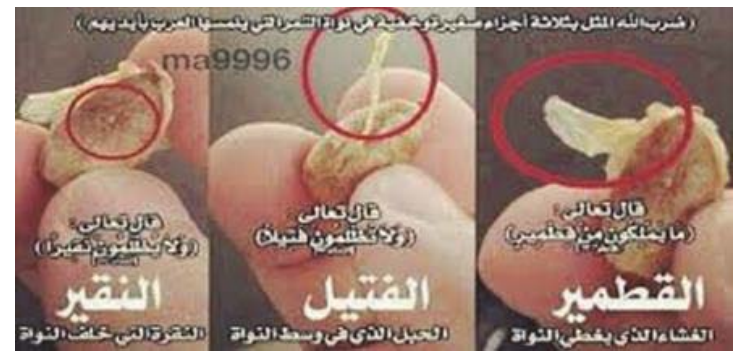

Figure 7: The small parts hidden in the nucleus of dates known as al-fatil, al-naqir and al-qitmir.

In a nutshell, Ibnu Al-Sakit says that al-fatil refers to something which is in the long slit of a date-stone. Al-naqir refers to speck on the back of a date-stone and al-qitmir is the thin membrane over the date-stone, resembling something that is worthless and insignificant.

\subsection{Quranic Descriptions of the Date Palm (Shajarah Tayyibah, Kull Hin and Min Linah)}

Allah has also described the date palm using different terms known as shajarah tayyibah, kull hin and min linah. In Surah Ibrahim verse 24:

\section{"...A goodly word as a goodly tree, whose root is firmly fixed and its branches reach the sky (i.e. very high)."}

The scholars differed regarding the meaning of shajarah (tree) that has been used as the metaphor of kalimah tayyibah (good word). Some of them view that it implies the date palm. In contrast, others opine that it refers to a tree in the heaven. Thus, the dispute is based on the different type or nature of the tree.

The researchers as Abu Ja'far are of the opinion that the first opinion is the best as it is in accordance with the authenticity of a report from the Prophet such as:

Ibn 'Umar narrated: "We were with the Prophet and fresh dates of a palm tree were brought to him. On that he said: Amongst the trees, there is a tree which resembles a Muslim. I wanted to say that it was the date palm tree but as I was the youngest of all (of them) I kept quiet. And then the Prophet said: It is the date-palm tree." 6 (Al-Tabari, 2000, p. 567)

In Surah Ibrahim verse 25:

"Giving its fruit at all times, by the Leave of its Lord and Allah sets forth parables for mankind in order that they may

${ }^{6}$ See al-Bukhari. (2000). al-Jami' al-Sahih al-Bukhari, chap. Al-fahm fi al-'ilm, vol. 1, p. 128, Hadith number 70. 
remember."

Ibnu 'Umar in his commentary says that it refers to the date palm which its leaves do not fall.

\begin{abstract}
Ibn 'Umar narrated: "While we were with Allah's Messenger he said: Tell me of a tree which resembles a Muslim man. Its leaves do not fall and it does not, and does not, and does not, and it gives its fruits every now and then. It came to my mind that such a tree must be the date palm, but seeing Abu Bakr and 'Umar saying nothing, I disliked to speak. So when they did not say anything, Allah's Messenger said: It is the date-palm tree. When we got up (from that place), I said to 'Umar: O my father! By Allah, it came to my mind that it must be the date palm tree. 'Umar said: What prevented you from speaking, I replied: I did not see you speaking, so I disliked speaking or saying anything. 'Umar then said: If you had said it, it would have been dearer to me than so-and-so."7
\end{abstract}

Anas and Mujahid mention that it refers to the date palm. Ibnu 'Abbas in his commentary on the verse: "Giving its fruit at all times" gives several interpretations. He reveals that it connotes the early morning and evening. It also means every hour, night and day, winter and summer. It includes something which is green, then becomes yellow. Besides denotes pieces of dates. It signifies a tree which brings forth fruits every six months as well as a year. (Al-Sayuti, 2003, p. 48-49)

Al-Tabari asserts that Ahl al-Ta'wil differed in the meaning of al-hin. The first group of scholars interprets al-hin as morning and evening. Ibnu 'Abbas for instance, reveals that it connotes to bear fruit every morning and evening. It also means to remember Allah every hour, night and day, winter and summer. Similarly, Al-Dahhak says that it symbolizes a believer who is in the obedience of Allah at all times; day and night. It includes something which is green, then becomes yellow. Besides denotes pieces of dates. It signifies a tree which brings forth fruits every six months as well as a year. It signifies a tree which brings forth fruits every time which resembles a believer who is in the obedience of Allah at all times; day and night, winter and summer.

The second group of scholars opines that al-hin signifies a tree which brings forth fruits every six months; i.e. between reaping when the tree produces fruits and yielding time; when the spadix appears.

The third group of scholars views that al-hin shows a tree which brings forth fruits annually.

The fourth group of scholars observes that al-hin shows the date palm brings forth fruits for every two months.

Abu Ja'far believes that the best opinion is al-hin implies every time; in the morning and evening as Allah made a parable; i.e. the date palm brings forth fruits every time alike the righteous deeds and words of a believer. Certainly, his/her righteous deeds and words will be brought before Allah every day; i.e. neither every year nor every six months nor every two months. Therefore, al-mathal (parable) is not contrary to al-mumaththil bihi in terms of the meaning. This is due to the fact that the date palm produces fruits; i.e. the spadix in winter and al-balh (unripe dates), al-busr (partially ripe dates), al-rutab (ripe/fresh dates) and al-tamar (dried dates) in summer. (Al-Tabari, 2000, p. 575-591)

According to Ahl al-Lughah (linguists), generally, the word al-hin is a noun which includes all times; long and short. The ayah: "Giving its fruit at all times" signifies that the dates can be benefitted at all times; day and night also summer and winter. Moreover, the date palm bears fruits every year thus, could be used at all times of the year. (Razi, 1992, p. 245) In Surah al-Hashr verse 5:

"What you (O Muslims) cut down of the palm-trees (of the enemy), or you left them standing on their stems, it was by Leave of Allah, and in order that He might disgrace the Fasiqun (rebellious, disobedient to Allah)."

Al-Suyuti exposes that it was revealed upon Bani Al-Nadir as mentioned in many hadith. For instance:

Hafs bin Ghiyath narrated: "Habib bin Abi Amrah narrated to us, from Sa'eed bin Jubair, from Ibn Abbas, regarding the saying of Allah, the Mighty and Sublime: What you cut down of the linah or you left of them standing on their trunks - he said: 'The linah is the date-palms.' That He might disgrace the rebellious. He said: 'They were forced from their forts.' And they were ordered to cut down the date-palms, that caused some hesitation in their chests, so the Muslims said: "We cut some of them and we left some of them, so let us ask the Messenger of Allah is we are to be rewarded for those that we cut down and if we will be burdened for what we left?" So Allah [Most High] revealed the ayah: "What you cut down of the linah or you left of them standing on their trunks."8

Ibnu 'Abbas views that linah refers to the date palm. It also connotes a tree or a type of dates. 'Ikrimah, Qatadah

7 See al-Bukhari. (2000). al-Jami' al-Sahih al-Bukhari, chap. Kashajarah tayyibah asluha thabit wa far'uha fi al-sama' tu'ti ukulaha kulla hin, vol. 14, p. 291, Hadith number 4329.

${ }^{8}$ See al-Tirmidhi. (n.d). al-Sunan, chap. Wa min surah al-Hashr, vol. 11, p. 115, Hadith number 3225. 
and al-Zuhri say that it includes all types of dates except al-'Ajwah. (Al-Sayuti, 2003, p. 452)

Ibnu Kathir says that it refers to a good type of dates. Abu 'Ubaidah opines that it includes all types of dates except al-'Ajwah and al-Barni. The majority of al-Mufassirun (explainer of the Qur'an) says that it includes all types of dates except al-'Ajwah. Mujahid observes that it also comprises dates of al- Buwairah. (Ibn Kathir, 1999, p. 61)

Ibn 'Umar said: "The Apostle of Allah burned the palm tree of Banu Al-Nadr and cut (them) down at Al Buwairah. So, Allah the exalted sent down "the palm trees you cut down or left."9

It has been said that the cause of revelation: The Jews said: O Muhammad! You had prohibited the mischief, hence why do you order to cut down the trees? As a result, Allah revealed the verse.

It has been also said that the cause of revelation is due to the fact that the Muslims forbade each other to cut the date palms as it is the spoils of Muslims, therefore the ayah was revealed approving those who forbade the cutting of the date palms as well as permitting those who support the cutting of the date palms from sin. In other words, both actions are legitimate as Allah says:"... it was by Leave of Allah, and in order that He might disgrace the Fasiqun (rebellious, disobedient to Allah)." (Shanqiti, 1988, p. 187)

Tantawi reveals that ma is ma shartiyyah in the position of nasab by qata'tum and min linah is to explain it. The verse: Fa bi idhnillah is regarded as jaza' al-shart. The letter lam is connected with something which has been eliminated.

Al-Alusi concludes that al-linah is absolutely refers to the dates. It is the fi'lah of al-laun. The letter ya' has been reversed by wau for the kasrah that comes before it, thus, the root word of al-linah is liunah. It has been said that besides it is absolutely refers to the dates it is also reflected the short date palms as well as its precious. (Tantawi, 2007, p. 4141)

\section{Quranic Treatment of Childbirth}

In modern obstetrics, the general trend is to utilize non-aggressive treatment methods that are quite safe, cheap few symptoms. According to the announcement of Ministry of Health and Medicine Education on giving priority to Islamic researches and Al-Qur'an advice of delivery manner of Maryam prescribed in Surah Maryam verses 22-26 and interpreter perception of these verses, date fruit is one of the best foods for women after delivery. Date fruit has calcium, serotonin, tannin and glucose that are important for bleeding control. (Khadeem N., 2007, p. 65)

Dates were the food of Maryam and there had been food that was better then, definitely Allah would command her to consume it. Allah the All-Wise has guided Maryam to shake the trunk of date palm towards her as it will let fall fresh ripe dates upon her. Then, He ordered her to drink and be glad.

This is a very wise prescription to comfort the childbirth as fresh ripe dates are just like water, hot and wet. They are favourable for and strengthen the cold stomach, increase the production of semen and fertility. Moreover, they are suitable for cold temperaments and are very nutritious. In addition, sweets like the fresh ripe dates are the fastest food to reach the liver and are favoured by the liver, especially when one eats ripe dates in which case the liver accepts it even more favourably benefits from it and then, transfers the benefit to the rest of the organs of the body. (Ibnu Qayyim, Prophetic Medicine, p. 488-489)

This verse has a tremendous scientific significance as dates are reported to yield tree times more energy than cereals. Experiments have also shown that dates contain some stimulants that strengthen the muscles of the uterus in the last months of pregnancy. This helps the dilation of the uterus at the time of delivery on one hand and reduces the bleeding after delivery on the other. Dieticians consider dates as the best food for women in confinement and those who are breast-feeding. This is due to the fact that dates contain elements that help in alleviating depression in mothers and enriching the breast-milk with all the elements needed to make the child healthy and resistant to disease. (Marwat, 2009, p.292)

In the light of the information available regarding nutritional value and potential health benefit of dates and given what is known about the benefits of good nutrition for pregnant women as part of a well-balanced diet. There is also anecdotal evidence to suggest that date fruit can contribute significantly to a healthy pregnancy by means of preventing anemia, reducing nausea, controlling blood pressure, regulating blood sugar levels, helping to restore depleted calcium, expelling toxins and increasing strength and immune resistance.

In addition, there are studies that show the benefits of date palm consumption on pre and post pregnancy. For instance, there is a study shows that 69 women who consumed six dates per day for 4 weeks prior to estimated date of delivery had significantly better childbirth in 5 aspects compared with 45 women who consumed none. The 5 aspects are:

${ }^{9}$ See al-Bukhari. (2000). al-Jami' al-Sahih al-Bukhari, chap. Hadith Bani al-Nadhir, vol. 15, p. 151, Hadith number 4505. 
1)Cervical dilation; the women who consumed date fruit had significantly higher mean compared with the non-date, 2)Spontaneous labour; occurred in $96 \%$ of those who consumed dates, compared with $79 \%$ women in the non-date fruit, 3)Use of prostin/oxytocin; was significantly lower in women who consumed dates (28\%), compared with the non-date fruit consumers (47\%), 4)Apparent latent phase of 1st stage of labour; $38 \%$ shorter compared to non-date group, 5) Fewer number of c-section compared to non-date group. (L. Al-Mehaisen, 2011, p. 29-31)

There is also a study involving 62 postpartum women, women who consumed 50 gram oral dates had significantly less bleeding compared to women given 10 unit of intramuscular oxytocin immediately after placental delivery. Blood loss mean significantly different in dates \& oxytoxin group. The use of dates after delivery decreases bleeding more than intramuscular oxytocin and it is a good alternative in normal delivery. (Khadeem N., 2007, p. 64-71)

\section{Conclusion}

The parts of date palm which have been described by the Qur'an are: its spadix, trunk, nucleus and date palm. The date palm spadix is described as soft, producing clusters of dates hanging low and near and being arranged and layered one above another. The trunk is said to be very uneven and rough; most appropriate for crucifixion as verified by the crucifixion of Musa and to be attached to during childbirth as confirmed by the delivery method of Maryam. The dead trunks are illustrated by the features of hollow and uprooted. The date palms are featured by grown from water; resembling other types of plants, some of them come from a single stem root and some are not, produce sheathed fruitstalks; enclosing dates and yield fruits of different taste which regarded as superior food and fruits. They are also described as good and produce fruits annually. Strong drink i.e. liquor could be also derived from dates i.e. before its prohibition. The nucleus of dates are characterized by the three small parts hidden known as al-fatil; something which is in the long slit of a date-stone, al-naqir, speck on the back of a date-stone and al-qitmir, the thin membrane over the datestone. The use of dates before delivery; reduces the need for induction and augmentation of labour and after delivery; decreases bleeding.

\section{References}

Abdul Baqi, M. F. (1994). Al-Mucjam al-Mufahras li Alfaz al-Qur'an al-Karim. Beirut: Dar al-Fikr \& Dar al-Ma'rifah.

Ahmad, Yusuf. (2012). Encyclopedia of Scientific Miracles in Al-Quran \& Sunnah. Selangor: al-Hidayah Publication.

Ahmed, Mushtaq, Mir Ajab Khan, Marwat, Sarfaraz Khan, Zafar, Muhammad, Aslam Khan, Muhammad, Ul-Hassan Tamoor and Sultana, Shazia. (2009). Useful Medical Flora Enlisted in Holy Quran and Ahadith. American-Eurasian J. Agric.\& Environ. Sci.

Azimabadi, Badr. (1997). Prophetic Way of Treatment. Pakistan: Darul Ishaat.

Badwilan, Ahmad Salim. The Miracle of Dates. PT Mizan Publika.

Bean, Anita, Hillin, Anthony, Hooper, Anne, McGee, Siobhan, MacIntyre, Michael, Munro, Robin. (1996). Health and Healing The Natural Way. Singapore: Colourscan.

Al- Bukhari, M. I. (2000). Al-Jamic al-Sahih al-Bukhari. Riyad: Dar al-Salam.

Chaira, N. (2007). Chemical composition of the flesh and the pit of date palm fruit and radical scavenging activity of their extracts. Pakistan Journal of Biological Sciences.

Al-Dhahabi, Muhammad bin Ahmad. (1989). Prophetic Medicine. Qahirah: Maktabah Qur'an.

Elleuch, M. (2008). Date flesh: Chemical composition and characteristics of the dietary fibre. Food Chemistry.

H. Bircher, Warda. (1995). Date Palm A Friend and Companion of Man. Egypt: Elias Modern Press.

Jumaily, Ahmad. The Benefits of 'Ajwah Dates and Significant Stories. (2013). Zainal Abidin, Sakina Begum. (ed.). Selangor: Ibnu Kathir.

L. Al-Mehaisen, H. Bawadi, S. Beitawi, Z. Amarin. (2011). The effect of late pregnancy consumption of date fruit on labour and delivery. Journal of Obstetrics \& Gynaecology.

Al-Razi, M. F. (1992). Mafatih al-Ghaib. Al-Qahirah: Dar al-Ghad al-'Arabi.

Al-Sayuti, J. (2003). Al-Durr al-Manthur fi al-Tafsir bi al-Ma'thur. Al-Qahirah: Markaz Hijr li al-Buhuth wa-al-Dirasat al-'Arabiyyah wa alIslamiyah.

Al- Sijistani, A. H. (1985). Ibrahim al-Sammaraa. (Ed.). Kitab al-Nakhl. Al-Mamlakah al-cArabiyyah al-Sucudiyyah: Dar al-Liwa' \& Beirut: Muassasah al-Risalah.

Al-Suyuti, Jalalu'-Din Abd'ur Rahman. (1986). al-Manhaj al-Sawi wa al-Manhal al-Rawi fi al-Tibb al-Nabawi. Beirut: Muassasah Kutub Thaqafiyyah.

Al-Tabari, M. (2000). Jami' al-Bayan fi Ta'wil al-Quran. n.p.: Muassasah al-Risalah.

Al-Tirmidhi, M. (n.d.) Ahmad Muhammad Syakir. (Ed.). Al-Sunan. Beirut: Dar al-lhya' al-Turath al-cArabi.

Kahrizi, Danial, Molsaghi, Mozhgan, Faramarzi, Akbar, Yari, Kheirullah, Kazemi, Elham. (2012). Medical Plants in Holy Quran. American-Eurasian J. Agric.\& Environ. Sci.

Khadeem N. , S. A., Latifnejad R., Hammod N., Ibrahimzadeh S. (2007). Comparing the Efficacy of Dates and Oxytocin in the 
Management of Hemmorhage. Shiraz E-Medical Journal.

Khafagi, Ishrak, Zakaria, Amira, Dewedar, Ahmed and El-Zahdany, Khaled. (2006). A Voyage in the World of Plants as Mentioned in the Holy Quran. International Journal of Botany.

Ibn 'Ashur, M. Tahir. (2000). Tafsir al-Tahrir Wa al-Tanwir. Beirut: Muassasat al-Tarikh.

Ibn Kathir, I. (1999). Tafsir al-Qur'an al-'Azim. n.p.: Dar al-Tayyibah.

Ibn Qayyim al-Jawziyyah, Muhammad bin Abu Bakr. (2008). Al-Tibb al-Nabawi. Al-Qahirah: Dar al-Hadith.

Marwat, Sarfaraz Khan. (2009). Fruits Plant Species Mentioned in the Holy Qur'an and Ahadith and Their Ethnomedical Importance. American- Eurasian J. Agric. \& Environ. Sci.

Mousavi, T. (2014). Nutritional value and health benefits of dates according to islamic recourses and traditional medicine. Journal of Mazandaran University of Medical Sciences.

Al-Shahib, W. and R. J. Marshall. (2003). The fruit of the date palm: its possible use as the best food for the future? International Journal of Food Sciences \& Nutrition.

Shanqiti, M. A. (1988). Tafsir Adwa' al-Bayan. n.p.: Maktabat Ibn Taimiyyah.

Tantawi, M. S. (2007). Al-Tafsir al-Wasit li al-Qur'an al-Karim. Beirut.: Dar al-Sa'adah.

Vayalil, P. K. (2012). Date fruits (Phoenix dactylifera Linn): an emerging medicinal food. Critical Reviews in Food Science \& Nutrition. 